\title{
Prevalence and characteristics of accidental perineal tears during childbirth in a communal medical center in Guinea-Conakry: a cross-sectional study
}

\author{
Oumou Hawa Bah*, Boubacar Alpha Diallo, Aboubacar Fode Momo Soumah, \\ Boubacar Siddi Diallo
}

Department of Gynaecology and Obstetrics, Gamal Abdel Nasser University of Conakry, Guinee

Received: 02 December 2019

Accepted: 18 December 2019

*Correspondence:

Dr. Oumou Hawa Bah,

E-mail: camarahawa2002@gmail.com

Copyright: () the author(s), publisher and licensee Medip Academy. This is an open-access article distributed under the terms of the Creative Commons Attribution Non-Commercial License, which permits unrestricted non-commercial use, distribution, and reproduction in any medium, provided the original work is properly cited.

\begin{abstract}
Background: Prevalence studies are still rare in sub-Saharan Africa on perineal tears. We conducted this crosssectional study in a communal hospital in Guinea-Conakry, with the objective of this study was to determining the prevalence and characteristics of post-obstetric perineal lesions.

Methods: All deliveries between March $1^{\text {st }}$ and August $31^{\text {st }}, 2014$ were reviewed. We included in the analysis all the single deliveries with perineal tears. The Anglo-Saxon classification of perineal tears was used.

Results: The prevalence of perineal tears was $5.7 \%$ with $5.4 \%$ benign lesions and $0.3 \%$ severe lesions. We did not register $4^{\text {th }}$ degree lesions. The average age of parturient was 22 years. The majority (96.6\%) of parturient had a history of genital mutilation and perineal scarring $(60.3 \%)$.

Conclusions: This prevalence appear low compared to those reported in other studies in Africa and point to the need for more sophisticated studies to have a better estimate of the prevalence of perineal tears in Guinea-Conakry.
\end{abstract}

Keywords: Delivery, Perineum, Prognosis, Traumatism

\section{INTRODUCTION}

Perineal lesions can occur spontaneously during vaginal delivery in women with fast or induced labor. There are several classifications for perineal obstetric lesions, but the Anglo-Saxon classification, the most used, distinguishes four degrees of increasing severity. ${ }^{1}$ In the first degree, the tear affects the perineal skin only. In the second degree, the tear affects the perineal muscles but spares the anal sphincter. The third degree corresponds to a tear associating a rupture of the external sphincter of the anus to one or more simple perineal tears. Finally, in the fourth degree, the anterior anorectal wall is broken creating a cloaca between the vagina and the rectum. The first two degrees are considered benign lesions, the third degree is described as a complete perineal lesion and the fourth stage is a complete complicated perineal lesion..$^{2-4}$

Perineal lesions of the $3^{\text {rd }}$ and $4^{\text {th }}$ degree is a concern for obstetricians because of the harmful consequences they may cause in the medium and long term on the health and quality of life of women. According to the literature, they are responsible for anal incontinence (gas, liquid and solid), defecatory emergencies, dyspareunia, lubrication disorders and psychological repercussions. ${ }^{3}$ The systematic review of the different aspects of women's long-term sexual lives after maternal obstetric morbidity, all causes combined, shows a higher prevalence of dyspareunia in these patients compared to women who did not experience significant morbidity at delivery. ${ }^{5}$ 
Urinary and fecal incontinence reduce quality of life and may lead to increased health care costs and medical interventions. ${ }^{3,6}$ Obstetric anal sphincter injury (OASI) is one of the most severe obstetrical complications and can occur in up to $5.9 \%$ of vaginal deliveries. ${ }^{7}$ It is the major cause of anal incontinence in young women and also a cause of major morbidity post-partum, both at short and long term, with a positive correlation with bladder, bowel and sexual dysfunction., ${ }^{7,8}$ Regardless of the type of delivery, anal incontinence occurs in a surprisingly large number of middle aged women. ${ }^{9}$ Pelvic floor disorders (PFD) cover a spectrum of conditions, including pelvic organ prolapse (POP), urinary (UI) and fecal incontinence (FI). Vaginal birth is considered the leading risk factor. ${ }^{10,11}$

The prevalence of severe perineal lesions varies across countries, obstetric practices, diagnostic means, and practitioner experience. ${ }^{4,12}$ According to the studies, their prevalence varies between 0.6 and 20\%.13,14 These prevalence's would be higher if occult lesions are taken into account. They would thus be $35 \%$ in nulliparous and $40 \%$ in multiparous. ${ }^{4}$ Several factors are considered to be associated with a high risk of severe perineal tears during vaginal delivery. These are primiparity, instrumental delivery, episiotomy, occipito-posterior presentation, induction of labor, a fetus weighing more than $4000 \mathrm{~g}$, and so on. ${ }^{4,15}$

But in Africa, literature is still very poor on perineal lesions. ${ }^{16-20}$ This study was therefore conducted with the following objectives: to determine the prevalence of postdelivery perineal lesions in a communal hospital in Guinea-Conakry, to describe the clinical and progressive characteristics of these perineal lesions as well as the socio-demographic characteristics of parturient.

\section{METHODS}

The framework of the study was the gynecology and obstetrics unit of the Ratoma Communal Medical Center (CMC), Conakry Prefecture, which has 5 CMCs. It is a level II public health facility in the country's health pyramid under its responsibility for urban health centers and a medical staff composed of: hospital practitioners; medical students, nurse anesthetists; State midwives and nurses; health aides and room girls.

\section{Type of study}

This was a cross-sectional study that covered the period from March 1 to 31 August 2014 that is six months in the gynecology department of the Ratoma CMC.

\section{Study population and sampling}

The study population consisted of women who gave birth in the gynecology and obstetrics department of the Ratoma CMC during the study period. All women who had a single delivery with perineal tear regardless of degree were included in the sample. Multiple deliveries and cesarean deliveries have been ruled out.

\section{Study variables}

All tears of the perineum were divided according to the Anglo-Saxon classification. ${ }^{1}$ Sociodemographic variables included age grouped into two categories (under 20 and 20 and over), marital status (married versus single), occupation (housewives, student and employed) and parity (primiparous versus multiparas). Clinical features included history of genital mutilation, duration of expulsion (less than 30 minutes and up to 30 minutes and above), condition of the perineum (perineal scar versus non-scar) and use of obstetric maneuvers. Newborn variables included birth weight (less than $2500 \mathrm{~g}, 2500$ $3999 \mathrm{~g}$ and $4000 \mathrm{~g}$ and above) and head circumference (less than $33 \mathrm{~cm}$ and $33 \mathrm{~cm}$ and above).

\section{Data collection and analysis}

Data was collected from delivery records, patient medical records, hospital records and by interviewing patients. A questionnaire was used for the collection, then the data was entered on Epi info 3.5.1 and analyzed. The results were presented in figures and tables.

\section{Ethical considerations}

The study was approved by health officials at the Ratoma CMC. Verbal consent was obtained from the participants and the cards were anonymous.

\section{RESULTS}

\section{Prevalence of perineal lesions}

A total of 1012 single vaginal deliveries were performed at the Ratoma CMC between March $1^{\text {st }}$ and August $31^{\text {st }}$, 2014. Of these, 58 presented post-obstetric trauma, a prevalence of $5.7 \%$. The 58 perineal lesions were divided into $30(51.7 \%), 25(43.1 \%)$ and $3(5.2 \%)$ lesions of the $1^{\text {st }}, 2^{\text {nd }}$ and $3^{\text {rd }}$ degree respectively. The specific prevalence were therefore $5.4 \%(\mathrm{n}=55)$ and $0.3 \%(\mathrm{n}=3)$ for benign perineal lesions and severe perineal lesions respectively.

Table 1: Sociodemographic, clinical and neonatal characteristics of the sample.

\begin{tabular}{|lll|}
\hline Characteristics & Number (n) & $\%$ \\
\hline Age group (year) & & \\
\hline Less than 20 years & 24 & 41.4 \\
\hline 20 years and above & 34 & 58.6 \\
\hline Occupation & & \\
\hline Household & 21 & 36.2 \\
\hline youth/students & 20 & 34.5 \\
\hline $\begin{array}{l}\text { Employees/liberal } \\
\text { profession }\end{array}$ & 17 & 29.3 \\
\hline
\end{tabular}




\begin{tabular}{|lll|}
\hline Characteristics & Number (n) & $\%$ \\
\hline Marital status & & \\
\hline Married & 53 & 91.4 \\
\hline single & 5 & 8.6 \\
\hline Parity & & 53.4 \\
\hline Primiparous & 31 & 46.6 \\
\hline Multiparous & 27 & \\
\hline History of genital mutilation & 56 & 96.6 \\
\hline Yes & 2 & 3.4 \\
\hline No & & 55.2 \\
\hline Expulsion period & 32 & 44.8 \\
\hline Less than 30 minutes & 26 & 60.3 \\
\hline 30 minutes and more & & 39.7 \\
\hline State of the perineum & 35 & \\
\hline Perineum scar & 23 & 29.3 \\
\hline Perineum without scar & & 70.7 \\
\hline Obstetric maneuver & 17 & 12.1 \\
\hline Yes & 41 & 77.6 \\
\hline No & & 10.3 \\
\hline Weight of newborn & 7 & 62.1 \\
\hline Less than 2500 g & 45 & 37.9 \\
\hline $2500-3999 \mathrm{~g}$ & 6 & \\
\hline $4000 \mathrm{~g}$ and more & & \\
\hline Cranial perimeter & & \\
\hline Less of 33 cm & 22 & \\
\hline 33 cm and more & & \\
\hline
\end{tabular}

\section{Characteristics of the sample}

The socio-demographic, clinical, and new-born characteristics of the sample are shown in Table 1. All mothers were practically married $(91.4 \%)$ or had female genital mutilation (96.6\%). The majority was at least 20 years old $(58.6 \%)$ or primiparous $(53.4 \%)$. The average age was 22 years (standard deviation $=7.64$ ) with extremes of 15 and 39 years old. The duration of expulsion was less than half an hour in $55.2 \%$ of cases and the perineum was scar in $60.3 \%$ of cases. Obstetric maneuvers were used in $29.3 \%(n=17)$ of the cases. It was the abdominal expression $(\mathrm{n}=15)$ and the sucker $(\mathrm{n}$ $=2)$. In $10.3 \%(n=6)$ of the cases, the new-born weighed at least $4000 \mathrm{~g}$ and in $37.9 \%(\mathrm{n}=22)$ of the cases, his head circumference was at least $33 \mathrm{~cm}$.

\section{Distribution of the sample according to the degree of the perineal lesion}

Table 2 shows the distribution of socio-demographic, clinical and neonatal characteristics according to the degree of perineal lesions. Primiparous were predominant in first degree $(56.7 \%)$ and third degree $(66.7 \%)$ lesions, whereas multiparous were slightly more numerous in second degree $(52 \%)$ lesions. Whatever the degree of perineal tears, new-borns from 2500 to $3999 \mathrm{~g}$ were the majority (more than two-thirds).

Table 2: Sociodemographic, clinical and neonatal characteristics by severity of perineal lesions.

\begin{tabular}{|c|c|c|c|c|c|c|c|}
\hline \multirow[t]{2}{*}{ Characteristics } & \multicolumn{2}{|c|}{$\begin{array}{l}1^{\text {st }} \text { degree lesions } \\
(n=30)\end{array}$} & \multicolumn{2}{|c|}{$\begin{array}{l}\text { Lesions of the } 2^{\text {nd }} \\
\text { degree }(n=25)\end{array}$} & \multicolumn{2}{|c|}{$\begin{array}{l}\text { Third degree } \\
\text { lesions }(n=3)\end{array}$} & \multirow[t]{2}{*}{ P-value } \\
\hline & $\mathbf{n}$ & $\%$ & $\mathbf{n}$ & $\%$ & $\mathbf{n}$ & $\%$ & \\
\hline \multicolumn{8}{|l|}{ Parity } \\
\hline Primiparea & 17 & 56.7 & 12 & 48.0 & 2 & 66.7 & \multirow{2}{*}{0.9520} \\
\hline Multiparous & 13 & 43.3 & 13 & 52.0 & 1 & 33.3 & \\
\hline \multicolumn{8}{|c|}{ Weight of newborn } \\
\hline Less of $2500 \mathrm{~g}$ & 5 & 16.7 & 1 & 4.0 & 1 & 33.3 & \multirow{3}{*}{0.9310} \\
\hline $2500-3999 \mathrm{~g}$ & 22 & 73.3 & 21 & 84.0 & 2 & 66.7 & \\
\hline $4000 \mathrm{~g}$ and more & 3 & 10.0 & 3 & 12.0 & 0 & 0 & \\
\hline \multicolumn{8}{|c|}{ Cranial perimeter } \\
\hline Less of $33 \mathrm{~cm}$ & 19 & 63.3 & 15 & 60.0 & 2 & 66.7 & \multirow{2}{*}{0.6275} \\
\hline $33 \mathrm{~cm}$ and more & 11 & 36.7 & 10 & 40.0 & 1 & 33.3 & \\
\hline
\end{tabular}

\section{Evolution of perineal lesions}

In $89.7 \%(\mathrm{n}=52)$ of the cases, the perineal suture did not present complications. The complications consisted of three lapses, two infections and one hematoma. A single birth resulted in a stillbirth.

\section{DISCUSSION}

The purpose of this study was to determine the prevalence of post-delivery perineal tears, to describe their characteristics and those of parturient victims of these tears. This results show an overall prevalence of $5.7 \%$. Specifically, benign lesions had a prevalence of $5.4 \%$ against $0.3 \%$ for severe lesions.

This overall prevalence is higher than the $0.91 \%$ reported by Gandzien in a basic hospital in Brazzaville. ${ }^{21}$ However, it was below the $19.2 \%, 9.2 \%, 8.1 \%$ and $15.7 \%$ reported respectively by Egbe et al, in a regional hospital in Cameroon, Fouelifack et al, at Yaoundé Central Hospital, Cissé et al, in a Dakar maternity ward and 
Fouelifack et al, between 2008 and 2010 at the central hospital of Yaounde. ${ }^{16,18-20}$ The diagnosis of perineal tears depends on the available diagnostic means but also on the practitioner's experience. Thus, Andrews et al, showed in a study involving 59 patients with complete tears in the perineum that $87 \%$ and $24 \%$ of these tears were not diagnosed by midwives and physicians, respectively. ${ }^{22}$ In this case, some diagnoses were made by midwives or general practitioners and could partly explain the low prevalence found in this study compared to other studies in Africa.

Perineal lesions were predominantly type 1 and 2 . Type 3 lesions accounted for only $5.2 \%$ of cases, whereas we did not record 4 th degree lesions. These results are consistent with trends observed in studies in Africa where benign lesions are generally ultra-majority. ${ }^{16-21}$ The prevalence of severe lesions was always less than $0.5 \%$. Higher prevalence of $2.95 \%$ to $9.7 \%$ were found for third- and fourth-degree perineal tears in Western countries. ${ }^{9,23,24}$ An underreporting of cases related to limited diagnostic means could explain the low prevalence observed in subSaharan Africa.

As in other African studies on the subject, the sample was very young with an average age of 22 years old, even younger than in other studies where the average age is between 24 and 27 years old. ${ }^{16-19}$ Despite this youth, $96.6 \%$ of the sample was women who had a history of genital mutilation. This prevalence is higher than the $72.9 \%$ of women with genital mutilation found in 2006 in the main Ouagadougou hospital in Burkina Faso. ${ }^{25}$ Above all, it suggests that recent campaigns against female genital mutilation are not bearing fruit and that the practice remains largely ingrained in Guinea-Conakry. Studies have shown that genital mutilation is associated with a higher frequency of perineal tears during deliveries in this setting. ${ }^{25}$

This high frequency of genital mutilation partly explains the importance $(60.3 \%)$ of the cicatricial perineum in the sample. However, studies have shown that perineal scarring is a factor associated with the occurrence of perineal tears and this is explained by the fact that fibrous tissue is more fragile than healthy tissue. ${ }^{17}$

In the short term, this result show very few complications such as suture release or infection. Gandzien had also found very few complications of the same type in the diaper suites in a basic hospital in Brazzaville. ${ }^{21} \mathrm{We}$ did not evaluate medium and long-term complications such as anal incontinence, sexual disorders which are the main dangers of perineal tears.

This study has several limitations. First, it was limited to one hospital and the results are not necessarily representative of what is happening in the country and even the capital. Then we only collected cases of perineal tears, which did not allow us to compare them with noncases to isolate associated factors. Finally, the deliveries were performed by practitioners of very different qualifications and experience, which significantly increases the risk of measurement errors for perineal tears.

\section{CONCLUSION}

This results show an overall prevalence of perineal tears of $5.7 \%$ much lower than those reported by many studies in sub-Saharan Africa. Regarding the types of tears, benign lesions predominated whereas severe lesions have a prevalence of only $0.3 \%$. This shows the need to conduct a prospective collection with personnel trained in the diagnosis of perineal tears in order to establish a more realistic prevalence of perineal tears in this context. Indeed, with the high proportions of scar tissue and genital mutilation in this countries and the too difficult working conditions, it is surprising to have such low prevalence.

Funding: No funding sources

Conflict of interest: None declared

Ethical approval: The study was approved by the Institutional Ethics Committee

\section{REFERENCES}

1. Harvey MA, Pierce M, Walter JE, Chou Q, Diamond P, Epp A, et al. Obstetrical anal sphincter injuries (OASIS): prevention, recognition, and repair. J Obstet Gynaecol Canada. 2015;37(12):1131-48.

2. Barbier A, Poujade O, Fay R, Thiébaugeorges O, Levardon M, Deval B. Is primiparity the only risk factor for lesions of the anal sphincter during childbirth? Obstet Fertii Gynecol. 2007;35(2):101-6.

3. Pizzoferrato AC, Samie M, Rousseau A, Rozenberg P, Fauconnier A, Bader G. Severe post-obstetric perineal tears: Medium-term consequences on women's quality of life. Prog Urol J Association Francaise. 2015;25(9):530-5.

4. Villot A, Deffieux X, Demoulin G, Rivain AL, Trichot C, Thubert T. Management of complete perineums (stage 3 and 4 perineal tear): literature review. La Revue Sage-Femme. 2016;15(1):10-8.

5. De Rham M, Meyer S, Achtari C, Fornage S. Long term consequences of obstetrical anal sphincter injuries on sexual function. Revue Med Sci. 2017;13(554):602-6.

6. Fenner DE, Genberg B, Brahma P, Marek L, DeLancey JO. Fecal and urinary incontinence after vaginal delivery with anal sphincter disruption in an obstetrics unit in the United States. Am J Obstet Gynecol. 2003;189(6):1543-9.

7. Joris F, Hoesli I, Kind A, Ries JJ, Kavvadias T. Obstetrical and epidemiological factors influence the severity of anal incontinence after obstetric anal sphincter injury. BMC Preg Childbirth. 2019;19(1):94.

8. Mous M, Muller S, De Leeuw J. Long-term effects of anal sphincter rupture during vaginal delivery: 
faecal incontinence and sexual complaints. Int J Obstet Gynaecol. 2008;115(2):234-8.

9. Nygaard IE, Rao SS, Dawson JD. Anal incontinence after anal sphincter disruption: a 30-year retrospective cohort study. Obstet Gynecol. 1997;89(6):896-901.

10. Pollack J, Nordenstam J, Brismar S, Lopez A, Altman D, Zetterstrom J. Anal incontinence after vaginal delivery: a five-year prospective cohort study. Obstet Gynecol. 2004;104(6):1397-402.

11. Callewaert MG, Albersen K, Janssen MS, Damaser T, Van Mieghem CH, van der Vaart J. Deprest: The impact of vaginal delivery on pelvic floor function delivery as a time point for secondary prevention, Int J Obstet Gynecol. 2016;123:678-81.

12. Ray CL, Audibert F, Cabrol D, Goffinet F. Obstetrics: A Comparative Study "Here-Elsewhere" Canada-Franc. J Obstet Gynaecol Canada. 2009;31(11):1035.

13. Faltin DL, Boulvain $M$, Floris LA, Irion $\mathrm{O}$. Diagnosis of anal sphincter tears to prevent fecal incontinence: a randomized controlled trial. Obstet Gynecol. 2005;106(1):6-13.

14. Nichols CM, Nam M, Ramakrishnan V, Lamb EH, Currie N. Anal sphincter defects and bowel symptoms in women with and without recognized anal sphincter trauma. Am J Obstet Gynecol. 2006;194(5):1450-4.

15. Dudding TC, Vaizey CJ, Kamm MA. Obstetric anal sphincter injury: incidence, risk factors, and management. Ann Surg. 2008;247(2):224-37.

16. Egbe TO, Kadzem LN, Takang WA, Tchounzou R, Egbe EN, Mbu RE. Prevalence and risk factors of perineal tears at the limbe regional hospital, cameroon. Int $\mathbf{J}$ Reprod Fertil Sex Health. 2016;3(3):70-8.

17. Fouedjio JH, Madi MTJ, Fouelifack YF, Fouogue TJ, Essiben F, Nana NP, et al. Factors associated with perineal tear at the maternity of the Yaounde Central Hospital, Cameroon. Health Sci Dis. 2015;16:4.

18. Fouelifack FY, Eko FE, Ko AC, Fouedjio JH, Mbu RE. Treatment of perineal wounds during the post partum period: evaluation of whether or not antibiotic should be systematically prescribed. Pan Afr Med J. 2017;28:144.

19. Fouelifack FY, Tameh TY, Mbong EN, Nana PN, Fouedjio JH, Fouogue JT, et al. Outcome of deliveries among adolescent girls at the Yaoundé central hospital. BMC Preg Childbirth. 2014;14(1):102.

20. Cisse CT, Niang M, Abdallah K, Faye EO. Perineal damage during childbirth. Af J Surg. 2014;3(2):94101.

21. Gandzien PC. Obstetric perineal tears at the Talangaï-Brazzaville Base Hospital. Black African Med. 2005;52(10):565-6.

22. Andrews V, Sultan AH, Thakar R, Jones PW. Risk factors for obstetric anal sphincter injury: a prospective study. Birth. 2006;33(2):117-22.

23. Faltin DL, Otero M, Petignat P, Sangalli MR, Floris LA, Boulvain M, et al. Women's health 18 years after rupture of the anal sphincter during childbirth: I. Fecal incontinence. Am J Obstet Gynecol. 2006;194(5):1255-9.

24. Laine K, Skjeldestad FE, Sanda B, Horne H, Spydslaug A, Staff AC. Prevalence and risk factors for anal incontinence after obstetric anal sphincter rupture. Acta Obstet Gynecol Scand. 2011;90(4):319-24.

25. Millogo-Traore F, Kaba ST, Thieba B, Akotionga M, Lankoande J. Maternal and foetal prognostic in excised women delivery. J Gynecol Obstet Repro Biol. 2007;36(4):393-8.

Cite this article as: $\mathrm{Bah} \mathrm{OH}$, Diallo BA, Soumah AFM, Diallo BS. Prevalence and characteristics of accidental perineal tears during childbirth in a communal medical center in Guinea-Conakry: a cross-sectional study. Int J Reprod Contracept Obstet Gynecol 2020;9:389-93. 